

\title{
The Doctrine of Leadership in the Greater Romantic Poets
}

\author{
B. H. LEHMAN
}

[Reprinted from the Publications of the Modern Language Association of America Vol. XXXVII, No. 4]

The Modern Langeage Association of America 



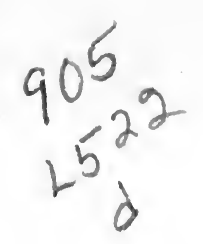

\section{THE DOCTRINE OF LEADERSHIP IN THE GREATER ROMANTIC POETS}

In his interesting discussion of the politics of the greater romantic poets, Mr. Walter Graham ${ }^{1}$ throws light not so much upon the work of the poets as upon the men themselves. The illumination is biographical rather than critical. Is it not possible to carry the analysis of the material further, to view the problem involved in the political doctrines of Wordsworth, Coleridge, Byron, and Shelley in such a way as to give a literary as well as a biographical significance to the data? The importance of such analysis for Scott, Southey, and Keats is less, and in any case cannot be undertaken in the present paper. With respect to Wordsworth, Coleridge, Shelley, and Byron, however, such a consideration has not only its own value but would confirm and also perhaps offer a correction of the biographical view.

In "the permanent politics of human nature"- to use Coleridge's phrase-as distinguished from party politics and domestic policies, the central fact for any political theory is its doctrine of leadership. To discover successively in the case of each of the four poets the nature and sources of authority, to fix the conception of leader explicit or implied and to indicate the importance of the result for a critical reading of the work of each poet is the object of this discussion.

Wordsworth and the Great MaN

Wordsworth's biographers have always made much of the crisis of his sympathy and love for France. And it is beyond question that with him, as with Coleridge, that crisis is the psychological key to the change from republicanism to a more

${ }^{1}$ P. M. L. A. XXXVI, 60-78. 


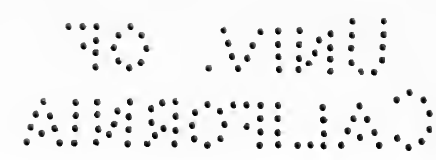

conservative point of view. ${ }^{2}$ His new doctrine he delivered in his great tract Concerning the Relations of Great Britain, Spain, and Portugal, to each other, and to the common enemy, at this crisis, and specifically as effected by the Convention of Cintra. What has never been adequately, if at all, pointed out is that the conception which lifts this tract upon the Miltonic plane includes a fusion of the fundamental ideas of equality and worth of men and of their capacity for sovereignty - though not under the earlier Rousseauistic nomenclature-with a conservative, certainly a less radical idea of great men. Wordsworth stands in a new light with regard to "the paradoxical reveries of Rousseau," but he none the less clings to the solider parts of them. These have coalesced into a new identity - "the wisdom of the people." For the present two sentences will suffice as testimony. "This was the feeling of the people; an awful feeling: and it is from these oracles that rulers are to learn." "The People might see, upon great occasions,-in the practice of its rulers-a more adequate reflection of its own wisdom and virtue." 3

Wordsworth's conception of a great man is implicit in all but his very earliest writing. It is explicit and even elaborated in the great tract and in the essay contributed to The Friend in 1809 , not many months after the tract was written. The great man is marked by "intellectual courage" which is found with "talents matured by experience without which it can not exist at all"; or with "the rapid insight of peculiar genius, by which the fitness of an act may be instantly determined, and which will supply higher motives than mere talents can furnish for encountering difficulty and danger, and will suggest better resources for diminishing or overcoming them," or with that fixed and habitual "principle, which implies the absence of all selfish anticipations, ... . and the inward disavowal of any tribunal higher or more dreaded than the mind's own judgment upon its own act." Best of all-at its

${ }^{2}$ See Ode, "Who rises on the banks of Seine."

3 Prose Works of William Wordsworth, London, 1896, II 205. 
highest-it is found with all three in one man. ${ }^{4}$ These gifts yield "the supreme comprehension of intellect and passion"; ; they lead to "elevation, the absolute possession of the individual mind, . . . a consistency or harmony of the being within itself, which no outward agency can reach to disturb or impair." This high quality governs the actions of heroes, statesmen, legislators, and warriors, produces the works of pure science and of the "combined faculties." The conception is the stuff of Wordsworth's most imposing political thinking and of his long-brewing philosophy of education; moreover, it was wrought into the fibre of many of his greatest poemseven before the Convention of Cintra pamphlet was undertaken. ${ }^{7}$ And in that conception the vox populi continued to hold a place, for into the generation about him the great man directs his "quickest glance." From it he learns as from an oracle,-but the power to determine what is oracular in the vox populi is enshrined in the great man's "elevation," for he disavows any higher tribunal. The great man is a selective focal point of the wisdom and virtue of nature and of ordinary men.

In Wordsworth's poetry are to be found enough restatements of this conception to establish it as a cardinal doctrine of the poet. There is the appeal to great men in the sonnet to Milton and the sonnet beginning

Great men have been among us.

Presentiments and many passages in The Prelude 8 revea the sources of the leader's power. As early as 1802 the leader and these sources are brought together in the sonnet to The King of Sweden.

I Ibid., I 129 ff.

'Ibid., I 208.

- Ibid., I 84 ff.

7 Wordsworth wrote in 1840 to Professor Reed: "It was . . . gratifying to me ... that you should have considered the Tract on the Convention of Cintra in relation to my poems . . " Memoirs of William Wordsworth Boston 1851, I, 418.

${ }^{8}$ E.g. Prelude V, ll. 39-41; XIV, 1l. 188-192. 
Who, taking counsel of unbending Truth,

By one example hath set forth to all

How they with dignity may stand. 9

Of the education of "The Governor" he wrote in 1801 with a half-conscious vision of his fullest theory,

'Tis not in battles that from youth we train

The Governor who must be wise and good,

And temper with the sternness of the brain

Thoughts motherly, and meek as womanhood.

Wisdóm doth live with children round her knees:

Books, leisure, perfect freedom, and the talk

Man holds with week-day mán in the hourly walk

Of the mind's business: these are the degrees

By which true Sway doth mount; this is the stalk

True Power doth grow on; and her rights are these. ${ }^{10}$

Nearly forty years later (1838) he described for the last forceful time the quality and character of heroic action.

Blest Statesman He, whose Mind's unselfish will

Leaves him at ease among grand thoughts: whose eye

Sees that, apart from magnanimity,

Wisdom exists not; nor the humbler skill

Of Prudence, disentangling good and ill

With patient care. What tho' assaults run high

They daunt not him who holds his ministry,

Resolute, at all hazards, to fulfill

Its duties; . . . n

And just half way between, in the Ecclesiastical Sonnets $I X$ :

Calm as an under-current, strong to draw

Millions of waves into itself, . . . the spirit of Nassau

Swerves not, ... from its end

Swerves not-diverted by a casual law.

Had moral action e'er a nobler scope?

The Hero comes to liberate, not defy; . . . 12

${ }^{9}$ Poetical Works, ed. Hutchinson, p. 305.

${ }^{10}$ Ibid., p. 304.

${ }^{11}$ Ibid., p. 514.

${ }^{12}$ Ibid., p. 442. 
But no one would be foolish enough to base a judgment on a few instances such as these from a poet who was sometimes capable of entertaining ideas not in perfect harmony with each other. Fortunately there spring to the mind of any reader of Wordsworth's poetry numberless occasions on which this theory of his manifests itself. One recalls that Rob Roy

... was wise as brave;

As wise in thought as bold in deed:

For in the principles of things

$\mathrm{He}$ sought his moral creed. ${ }^{13}$

Dion and especially its conclusion stir in one's memory. There are among many other sonnets, Seathwaite Chapel and London, 1802. Indeed, this theory lights up-nothing else could do so-the tributes to Schill, to Hofer, to Palafox, the lines written in expectation of the Death of Mr. Fox, the portrait of Burke, and the passage in The Prelude (XIV, 112) beginning

Such minds are truly from the Deity.

Many, many poems on political and ecclesiastical subjects, notably sonnets, are newly significant in this light. The sonnet To Toussaint L'Ouverture becomes at once something deeper, and something more precise, than a scmi-pantheistic, semi-mystic tribute to an individual. And, with all its admirable economy of policy, the Character of a Happy Warrior rests upon the law of reason. $\mathrm{He}$

Through the heat of conflict, keeps the law

In calmness made, and sees what he foresaw.

Over all such instances hangs the capital instance of Wordsworth's own conception of himself. For Wordsworth conceived himself as forming in the mould of the ideal leader. There is The Prelude ${ }^{14}$ to prove it, The Recluse, and certain of the sonnets and letters. In all these we have not only the leader, but the source and quality of his leadership.

${ }^{13}$ Ibid., p. 291. 
Finally, we have to assure ourselves that this theory and practice of Wordsworth is in thorough agreement with the fundamentals of his general philosophy. The latter "depends upon the asserted identity between our childish instincts and our enlightened reason." 15 Sir Leslie Stephen, whom I have just quoted, elaborates thus: "Our vague instincts are consolidated into reason by meditation, sympathy with our fellows, communion with nature, and a constant devotion to 'high endeavors.' "'16 Sir Leslie's categories are not strictly ours, but they so nearly coincide that no one would find contradiction in them. But should we not choose to appeal to such authority, we may make our own affirmation. The terms of the great man theory are the essential terms of all Wordsworth's teaching, as indeed the quotations from The Prelude and The Recluse prove: Reason, Nature, Unbending Truth, Virtue, Duty (resolute obedience to the vision seen). And, whether Wordsworth would have been pleased at the thought or not, a leadership theory is a more logical development of his general philosophy than a maundering sureness that every dalesman within thirty miles of Rydal Water was sensitive to the high things whose dwelling is the light of setting suns-and more consistent with the neighborly facts.

II

\section{Coleridge: The Statesman and the 'Clerisy.'}

For Coleridge's change from an early radicalism to a more conservative position, Mr. Graham's case is clear. Yet in themselves the earlier doctrines are not soluble in the later. So much is certain. We must examine the evidence to see what new idea harmonized these oppositions, and what in-

${ }^{14}$ See e.g. Prelude XIV, 11. 147 ff., Recluse, Part First, 11. 669 ff. and sonnets 'composed while the author was engaged in writing a tract occasioned by the Convention of Cintra.'

${ }^{15}$ Stephen, Hours in a Library, London, 1907, III, 146-7.

16 Ibid., 166. 
fluence of idea or of event moved him from one position to the other.

The psychology of the situation is simple. Coleridge, like others who once held faith in the wisdom and righteousness of the proletariat, found himself convinced by the French events that the theories upon which he had once explained them were not true. He inherited at this juncture the best of Burke's conservatism. The people were not compact of vision and the power to initiate achieving action. The Voice of God was, at the least, not always in residence in the people. The more unquestioning heard the voice, no longer audible in that quarter, speak from the Man of Destiny. Men of thought, like Wordsworth and Coleridge, with unerring logic brought themselves to a new, founded position. What the new position was, exactly, and how, in the case of Coleridge, it was arrived at is clear from the following passage. On April 29, 1832, to whatever auditors were at Highgate, Coleridge said:

I never said that the vox populi was of course the vox $D e i$. It may be; but it may be, and with equal probability, a priori, vox Diaboli. That the voice of ten millions of men calling for the same thing is a spirit, I believe; but whether that be a spirit of heaven or hell, I can only know by trying the thing called for by the prescript of reason and God's will. ${ }^{17}$

The new doctrine, then, does not desert for good and all the old, that vox populi is Vox Dei. But it subjects the popular will to the test of reason and divine intent in the mind of one who has knowledge of the high and holy prescript. In other words the new idea of leader is introduced, a leader with power to affirm or forbid.

Coleridge, indeed, pretty freely recognizes that there are men of a common order and men of genius. ${ }^{18} \mathrm{He}$ without question sets aside as a superior the gifts and services of

${ }^{17}$ The Complete Works of Samuel Taylor Coleridge, New York, 1854, Table Talk, VI, 393.

18 Ibid., VI, Table Talk, 318, 380, 415. 
"the Cranmers, Hampdens, and Sidneys."'19 And he recognizes with some explicitness, though not with rigorous consistency, the three orders of mental capacity that Machiavelli designates. ${ }^{20} \mathrm{He}$ translates: "There are brains of three races. The one understands of itself; the other understands as much as is shown it by others; the third neither understands of itself, nor what is shown it by others." ${ }^{21}$ In The Friend he introduces the quotation with "Machiavelli has well observed." The first order is genius. Its capacity to "understand of itself" is a gloss on the cryptic "the greatest and best of men is but an aphorism." "22 Genius is "the action of reason and imagination." ${ }_{23}$ This action affords "one of the most characteristic and infallible criteria of the different ranks of men's intellects . . . the instinctive habit which all superior minds have of endeavouring to bring, and of never resting till they have brought into unity the scattered facts which occur in conversation, or in the statements of men of business." ${ }^{24}$ The second order-the taught-finds itself illustrated by those persons, for example, who in philosophy are incapable of pushing back the frontiers in speculative science but to whom the charted science need not therefore be a terra incognita. ${ }^{25}$ The distinction between these two orders is made perfectly clear by the phrase: "the few men of genius among the learned class." 26 The nature of the third class, the not-learned, is set beyond doubt by a passage in The Statesman's Manual: "To the immense majority of men, even in civilized countries, speculative philosophy has ever been, and must ever remain, a terra incognita."27 The whole matter under consideration is neatly touched off by

"Ibid., II, The Friend, 68.

${ }^{20}$ Ibid., I, The Manual, 427; II, The Friend, 114-115.

"I Ibid., I, The Manual, 427.

22 Ibid., I, Aids, 129.

23 Ibid., VI, Table Talk, 319.

24 Ibid., VI, Table Talk, 380.

"Ibid., I, Manual, 428; Biographia Literaria, III, 251.

: Ibid., III, Biographia Lileraria, 251.

${ }^{27}$ Ibid., I, Statesman's Manual, 428. 
the "profaccia with a desponding sigh" in The Statesman's Manual: "From a popular philosophy and a philosophic populace, Good Sense deliver us!'28

The basis for Coleridge's idea of a great man lies in that "contradistinction of the understanding from reason-for which," he writes in 1825, "during twenty years I have been contending." 29 "By the 'understanding,' I mean the faculty of thinking and forming judgments on the notices furnished by the sense, according to certain rules existing in itself, which rules constitute its distinct nature. By the pure 'reason,' I mean the power by which we become possessed of principles." "The reason itself is the same in all men, yet the means of exercising it, and the materials, - that is, the facts and conceptions - on which it is exercised, being possessed in very different degrees by different persons, the practical result is, of course, equally different." ${ }^{31}$

The greatness of the mind, then, depends upon its bringing into unity with themselves and all things all the facts and conceptions, that is, upon the power to make the understanding serve the reason and the reason subserve the understanding. It is the function of reason in this reference "to comprehend," that is, to subordinate the notions of sense and the rules of the understanding's experience to absolute principles or necessary laws. Thus the reason "comprehends" all in the unity. ${ }^{32}$

If, now, we bring together the elements so far set forth we find that the laws or principles of reason and the regulations of prudence or understanding can make contact only in the unifying mind of superior men. This indeed, in practice, is Coleridge's conception. Pure reason in its fullness is Almighty Wisdom. "The laws of the Hebrew Commonwealth," for example, "which flowed from the pure reason, remain and

\footnotetext{
${ }^{28}$ Ibid., I, Statesman's Manual, 442.

${ }^{29}$ Ibid., I, Aids, 257.

${ }^{30}$ Ibid., II, The Friend, 164.

sI Ibid., II, The Friend, 148.

${ }^{32}$ Ibid., II, The Friend, 146.
} 
are immutable." From the statesman "we have a right to expect a sober and meditative accommodation to our own times and country of those important truths declared in the inspired writings for a thousand generations." ${ }^{33}$ Here then is that "prescript of reason" by which the leader, Wordsworth, Coleridge, or another, shall try the vox populi to discover whether it be vox Dei or vox diaboli.

The development of Coleridge's conservatism, which is nothing more than the subjection of the vague urges of a populace or a mob to the control of a seer, may be traced at the critical moment in his so-called political poems. In The Destruction of the Bastille and the lines To a Young Lady, the approval is for the freeing of Freedom-nothing more. Of the twelve sonnets in the Juvenile Poems, several exalt individual genius, one or two imply the value of the great leader to the cause of liberty, and the sonnet to Priestley looks with sharp disapproval upon the voice of the people and its result in the special case.

Though roused by that dark Vizir Riot rude

Have driven our Priestley o'er the ocean swell; . . .

In Religious Musings, in which the French Revolution is heralded as the beginning of that great upheaval of the innumerable tribes of the oppressed, not only are these tribes roused by "eloquent men" "stung to rage with pity," but "the mad careering of the storm" thus set going is tamed by "Philosophers and Bards,"

Conscious of their high dignities from God,

Enamored with the charms of order ...

and hating "the unseemly disproportion." 34 These, who realize the charms of order, are "Coadjutors of God," "the elect of Heaven," and their function is to dart their strong eye through the deeds of men and to adore steadfastly, yet

a3 Ibid., I, Manual, 423.

st Ibid., VII, Poems, 77. 
humbly, Nature's essence, mind, and energy -in short what Coleridge later designated "Reason."

The Destiny of Nations carries us forward by a definition of freedom.

For what is freedom but the unfettered use

Of all the powers which God for use had given?

But chiefly this, him first, him last to view

Through meaner powers and secondary things

Effulgent, as through clouds that veil his blaze. ${ }^{25}$

It is not the possession of those

who deem themselves most free

When they within this gross and visible sphere

Chain down the winged thought, scoffing ascent,

Proud in their meanness. ${ }^{36}$

The Ode to the Departing Year adds nothing. France, an Ode is the record of the crisis in the poet's soul, which followed France's assault upon Switzerland. So after all, runs the burden of the conclusion, the great upheaval was the vain rebellion of "the Sensual and the Dark," was not informed by the voice of God. Fears in Solitude, written in April of 1798, is a call to Britons. The lines have fed on bitter disappointment, but they confirm the Ode.

When we assemble the evidence of the poems, we find, then, that freedom of man, liberty, is through them all the continued object of the poet's devotion. Nevertheless, from the first he does not exclude freedom secured to men by a Kosciusko, let us say; specifically in his most elaborate statement he not only allows to the "Coadjutors of God" the initiation and propulsion of freedom's ideals but also assigns to these "Philosophers and Bards" the task of molding to perfect forms the "confusions" of "the outrageous mass." Finally - and with intensest significance-his own reversal of judgment on the French upheaval is based soundly on his devotion to freedom and illustrates, in his own person, the

${ }^{35}$ Ibid., VII, 83.

${ }^{36}$ Ibid., VII, Poems, 83. 
Philosopher and Bard trying events by the prescript of reason and concluding that vox populi is in the instance before him vox diaboli.

In the light of the same doctrine, Coleridge's conception of the jus divinum of kings becomes an intelligible matter. For the "direct relation of the state and its magistracy to the Supreme Being" 37 is merely the fact of the unity of reason and the access to reason of all men fit to rule. And it is to be remembered that, though "the reason hath faith in itself in its own revelations," by his acts a man of power may write himself down a demagogue,$^{38}$ and no leader. Camiola seems almost to have had her eye on this teaching when she addressed the King of Sicily:

Since, when you are unjust, the deity

Which you may challenge as a king, parts from you.

In the same light, too, much of the material interpolated in The Friend for entertainment of the reader and refreshment -God save the mark!-after the philosophical disquisitions, becomes significant, taking on for the reader the associative values that it bore in the author's mind. For example: in Essays XI and XII of the General Introduction Napoleon is finally ruled out of court as "the mimic and caricaturist of Charlemagne.", 39 Charlemagne more or less is accepted at Alcuin's evaluation as the embodiment of the Platonic philosopher become king. Napoleon is no philosopher and no king because he takes to mimicing his predecessor's acts instead of accommodating anew to the circumstances the principles and prescript of Reason. Likely enough, had Coleridge known Eginhard's document he would have ruled out Charlemagne for his attempt at an Augustus Redivious. Nevertheless, though this throws a question at the doctrine itself, the choice and treatment of the material is illuminated.

${ }^{37}$ Ibid., I, Manual, 429.

${ }^{39}$ Ibid., VI, Lay Sermon, 170-1.

${ }^{39}$ Ibid., II, The Friend, $79 \mathrm{ff}$. 
Of Coleridge's praise of Sir Alexander Ball nothing more need be said than that, if his perspectives were crooked and his judgment wrong, the exaltation of the little great man was orthodox, well within the teaching. In his recondite Royal Society Essay on the Prometheus of Aeschylus, ${ }^{40}$ even one in the porch of the temple can see the god out of the machine: for Aeschylus, the Eleusinian, has concealed in his tragedy and poetry (so says S. T. C.) a philosophema. The mythos of the colossal hero is "the generation of the vous, or pure reason in man!"41 Upon no other theory can I explain Coleridge's explanation than upon his obsession with the doctrine of leader as already set forth. This Coleridge who uplifted Sir Alexander Ball and degraded the Prometheus Bound is, one reminds oneself, the Coleridge who protected his leader against quack competition by telling the Higher Classes of Society how to recognize the demagogue with eleven tests, ${ }^{42}$ at least four of which we might here turn upon the analyst himself.

For Coleridge regarded himself as leader, beyond question. It was the basic inconsistency of his earliest addresses that they were "Conciones ad Populum"-the discourses of a leader. In Lines on a Friend, written in his youth, he says,

To me hath Heaven with bounteous hand assigned

Energic Reason and a shaping mind,

The daring ken of Truth, the Patriot's part . . . 13

And long before Coleridge sat upon Highgate Hill mumbling to his disciples, he was leading statesmen to the fountain of political truth, and philosophers to the source of Reason. The Highgate Table Talk is proof for the latter end; just as the tone of the addresses is for the first-not to speak of his judgment after the Swiss episode, that the vox populi in France was not vox Dei, but vox diaboli. The serious concern

${ }^{40}$ Delivered May 18, 1825.

${ }^{41}$ Complete Works, IV, Essay on Prometheus, 351.

${ }^{42}$ Ibid., VI, Lay Sermon, 170-1.

${ }^{43}$ Ibid., VII, Poems, 56. 
over his success and failure with the distinction of Reason and Understanding is evidence in the interval. The best of all evidence, however, if we hold in mind the relation of the great man to the learned classes, is the correction in Coleridge's own hand upon the title page of a copy of the Statesman's Manual. ${ }^{4}$ After the words A Lay Sermon Addressed to the Higher Classes of Society, the author has added but more particularly to the Learned.* The asterisk guides to the following footnote: "So it was ordered to be printed, and so, I believe, it was advertised." Futhermore, by merely measuring against his doctrine Coleridge's method of performance-with him so conscious a process!-it would be clear to a child that he conceived himself with some wistfulness but with some complacency, also, as leader.

It still remains to point out that the rights and duties of the early Jacobinical faith, recognized in the problem of government by Rousseau, maintain their place in the new scheme. For since Reason is resident in all men, every man may unite himself to the form of society planned and perfected by the leader in accordance with the prescripts of Reason and yet obey himself only and remain as free as before. Thus with both poets the leader is the interpreter of the will of all.

III

\section{Shelley: The Liberator}

The youth of Byron and Shelley, coming twenty years after that of Wordsworth and Coleridge, was subjected to different influences. And for all their democratic zeal they were strongly taken with the glamor of the Man of Destiny. With them consequently the great man is a more salient feature. Shelley comes chronologically last in this group, but psychologically he precedes Byron.

At the outset we must remind ourselves that the universe struck Shelley as a myth-maker and poet, and it struck him as what may be termed a humanitarian or sociological

"In the Widener Collection, Harvard College Library. 
philosopher. The world that struck the poet in these distinct ways is in the large a sociological laboratory. In it certain facts like winds, and dropping leaves, and sweet voices that fall silent are quite outside sociological generalizations. For them he is a lyre. All other facts he forced to submit to the analysis of his reason. He discovers a formula and, like all his kind, he thinks he has found the philosopher's stone.

This formula presents the human situation in terms of good and evil. Shelley is a perfectibilist. Love is the sole law which should govern the moral world. ${ }^{45}$ Under its sway all men will be good. The misery of men is not grounded in nature or in the tyranny of the Maker, but is caused by "the absence of reason." 46 Who shall introduce reason? The leader. How? "By an unadorned display of moral truth." So shall men be liberated. Shelley's own practical devices as an eager reformer seem small when compared with the cosmic convulsions of the Prometheus. Yet in spite of the distance measured between the real world and the ideal, Percy Bysshe Shelley and Laon and Prometheus are one type. They are, in Shelley's mind, the enemies and victims of tyrants, the idealized benefactors of men who for their efforts to bring men happiness suffer oppression.

Slave, tyrant, rebel-these constitute the Shelleyan triangle.

The slave and the tyrant are twin-born foes. ${ }^{48}$

When Liberty, inducted always by rebelling men, comes,

... tyrants and slaves are like Shadows of night

In the van of the morning light. ${ }^{49}$

${ }^{45}$ The Complete Poetical Works of Percy Bysshe Shelley, ed. Hutchinson, 1914 , p. 37.

${ }^{46}$ Notes to Queen Mab.

47 Irish Pamphlet, written with this conviction.

${ }^{48}$ Poetical Works, ed. Hutchinson, 1914, p. 571.

${ }^{49}$ Ibid., p. 616. 
The rebel may be the lowliest of men; his name may be legion. Hear the trumpeting last line of The Mask of Anarchy:

Ye are many-they are few.

But when, as in The Revolt of Islam, an army of rebellious patriots moves upon the oppressors, they meet disaster. A leader is needed: his mere name-Laon-turns defeat to victory and he is proclaimed

The friend and the preserver of the free!

Since the aim of the leader here is to create a perfectibilist world, it follows that in the ideal anarchy of universal intelligence he becomes useless. $\mathrm{He}$ is therefore a temporary phenomenon. Shelley takes casual note of this fact in the sonnet on Political Greatness. Political greatness creates a world in which it is not needed. This is practically illustrated in the conclusions of Shelley's plots-and explains these. Upon what he himself would have spent his humanitarian energy in such a world, there is no hint.

There are three longer works which deal with social questions: Queen Mab, 'The Revolt of Islam, and Prometheus Unbound. In the first, a juvenile piece entirely under the influence of Godwin, ${ }^{50}$ there is no sign as to how the ultimate millenium is to be achieved, though there is a vision of it. In the second a fleeting glimpse of the millenium is attained. In the third good begins its eternal reign. This progress in achievement moves on, pari passu, with the potency of the liberator. In Queen $M a b$ the future does not become the present. Two conditions are set side by side, without any hint as to how the change is to come. It may be that there is no change because there is no leader; it may be that there is no leader because the change is not depicted. The Revolt of Islam does not arrive at the end Shelley dreamed because the forces of right have no adequate protagonist. Or, once more, it may be that the leader fails Shelley because he does

${ }^{50}$ B. S. Allen: Shelley and Godwin, Unpublished dissertation in Harvard College Library, p. 325. 
not see quite what the leader is to achieve. But the humanitarian ideal in relation to the shameful present is taking a clear shape; and step by step the need of a chief mover is becoming clear. In Prometheus Unbound we come near to a final position. But when at length the Spirit of the Hour blows upon "the fairest shell of Ocean," and the prophesy of "one brotherhood" is achieved, the liberator-as liberatorbeing useless drops out of sight. Act IV has no place for Prometheus, unless we were to suffer the bathos of hearing him exalt his own good and perfect work.

Shelley's conception of a leader is that of a reformer not that of a philosopher. $\mathrm{He}$ is concerned with an instrument for achieving freedom,-religious, political, economic. The sources of a leader's gift, the nature of it, how specifically he is to enlighten the world, these are not his affairs. Great men are excellent in proportion as they defy and strike down tyranny. He illustrates his theory in his own practice and in that of his heroes. Sometimes his writings are the weapons of his assault, sometimes they depict the assault upon tyranny of other real or imagined people. Of the illustrations as of the theory it must be said that they are at home in the mind of an indignant visionary, somewhat obsessed by a vulgar love of confrontations in which the high are cast down and the lowly raised up. (Ozymandias has a much more precise motive than sadness at the shortness of man's works.) The whole conception has not the completeness of mind that looks before and after and sees the great world in the little.

\section{IV}

\section{ByRoN: THE REBEL}

Byron had, like Shelley, an unconquerable social interest. It comes out everywhere in what is enduring in his writings. It comes out not least of all in the use he makes of his sense of beauty. He, himself, and his heroes, when they are most isolated from humanity, are most bound to it by ties as deep as the human heart. Their division is negative, forced upon 
them by society, not positive, the result of desire. Rebellion against the world and the world's law is their course. They seek life unconditioned. So to him-and to the heroesnature is the consoler, and not infrequently leads through consolation to a new, ideal union with the world that is to be.

The mountains look on Marathon-

And Marathon looks on the sea;

And musing there an hour alone,

I dream'd that Greece might still be free. ${ }^{.1}$

But almost as frequently the consolation breeds a savage pity for self and self's trials. There result two Byrons-and two types of heroes in the poems.

It is the fault of certain critics that they do not make this distinction, and that, in one phrase or another, they depict Byron dragging the pageant of his bleeding heart through Europe. They interpret Missolonghi as a pose. They can not have read the letters. A noble desire to espouse the cause of those who seek any temporal improvement runs through them. In the "war of men with monarchs," he would give his blood. ${ }^{52}$ He speaks almost with yearning of an Italian republic. ${ }^{53}$ Yet he knows that the dream can be made real only by leaders. "If the Neapolitans have but a single Massaniello amongst them, they will beat the bloody butchers of the crown and sabre." ${ }^{54}$

\section{Let one living head, But one arise,-we come, we come!}

As the hope of some such leadership waned, he thought-and spoke-of taking a part in the business himself. ${ }^{55}$ His part

${ }^{51}$ The Poetical Works of Lord Byron, Oxford edition 1914, Don Juan, III; cf. also Childe Harold, IV, cLxxvin.

${ }^{52}$ The Works of Lord Byron: Letters and Journals, ed. R. E. Prothero, London, 1898, V, 383, 403.

${ }^{53}$ Ibid., 155.

${ }^{54}$ Ibid., 188-9.

${ }^{55}$ Letters and Journals, VI, 112; cf. also V, 20 and VI, 257. 
would have been a leading one whether for good or for bad, as that last Greek adventure was to prove.

For I will teach, if possible, the stones

To rise against earth's tyrants.

The same aspect of Byron shows through-with a bit of flourish, one feels-in the comment on the brilliant narrative of his taking in the murdered military commander. "I shall," he writes, "never be deterred from a duty of humanity by all the assassins of Italy, and that is a wide word." 56 Of one Byron "a duty of humanity" was the watchword. To the last he dreamed of leading men to a less conditioned life. The other uttered sobs of personal anguish and his bittersweet "gypsy laughter from the bushes," for he saw himself no hope of a life less cabined.

The famous dictum, then, that Byron is the hero of all his poems is misleading. For if there are two Byrons there may be two kinds of heroes. So it proves.

There are those whom we may represent by Lara. Lara moves as Byron would have, among the amazing properties of the Gothic romance. Clearly this hero is not bent on serving his kind. He differs seriously from Byron only in his tight-lipped habit. He is almost inarticulate, which the real Byron was never for one moment in all his life. But the "scattered dints of many a scar" 57 and the accumulated weight of the narrator's phrases imply that he sought once to find for himself through physical protest a free environment. ${ }^{-} \mathrm{He}$ could not, and his cheek never changed "from its callow gloom." At the last "a calm disdain. . . rose to reconcile him with his fate." 58 Childe Harold, "the world's tired denizen"59 expresses the philosophy upon which Lara acts.

Existence may be borne, and the deep root

Of life and sufferance make its firm abode

b6 Ibid., V, 136.

${ }^{67}$ Lara, II, Xxm.

s8 Ibid., II, XXII.

s?. Childe Harold, II, xxvI. 
The bare and desolated bosoms: mute The camel labors with the heaviest load, And the wolf dies in silence,-not bestowed In vain should such example be; if they, Things of ignoble or of savage mood, Endure and shrink not, we of nobler clay May temper it to bear,-it is but for a day. ${ }^{60}$

The situation which prompts this reaction is simple:

First Freedom, and then Glory-when that fails, Wealth, vice, corruption,-barbarism at last.ol

Harold, Lara, and their like dream of the glorious Freedom which in their time has departed from the earth; for a day, perhaps, they struggle to bring it back. But struggling decays into protest, protest into grim despondence. The cause of this declension is that the hero thinks of and yearns for his right of humanity, instead of concerning himself with his duty of humanity.

Byron could, however, interpret rights in terms of duties. His preoccupation with Prometheus is significant. Yet Prometheus is not the perfect type of those of Byron's heroes who are more than egoists. Shelley once pointed out that "The only imaginary being in any degree resembling Prometheus, is Satan,"62 and Carlyle asserted that "Satan also is Byron's grand exemplar, the hero of his poetry, and the model apparently of his conduct." ${ }^{\prime 63}$ Shelley, furthermore, carefully marked the distinction between the two figures. They both are characterized by "courage and majesty, and firm and patient opposition to omnipotent force"; Prometheus is "exempt from the taints of ambition, envy, revenge, and a desire for personal aggrandisement," and Satan is not. ${ }^{64}$ The difference is that Prometheus is actually a whole being, all the contradictory elements brought into a reverend unity, and

60 Ibid., IV, xxI.

${ }^{61}$ Ibid., IV, cvirr.

62 Preface to Prometheus Unbound.

${ }^{63}$ Carlyle, Critical and Miscellaneous Essays, London, 1857, I, 238.

${ }^{64}$ Preface to Prometheus Unbound. 
that in Satan the contradictions are still contradictory. This, it seems to me, must be what Carlyle had in mind when he said Satan is Byron's grand exemplar. ${ }^{65}$ Now, though Byron's noblest heroes may be said to oppose the moral law for the purpose, in part, of advancing their own interests, their opposition is not grounded in a wilful desire to secure their own rights but in a courageous and majestic ambition to secure the rights of others against an omnipotent force. In this way duty enters into the formula.

In Cain the stimulus is Lucifer himself. It is possible, even, to rationalize Lucifer as the rebellious thought of man.

Cain: How!

You know my thoughts?

Lucifer: They are the thoughts of all

Worthy of thought;-'tis your immortal part

Which speaks within you. ${ }^{60}$

Cain's complaint against Adam and Eve is that they served themselves with no eye, no love for their offspring. Their rights, not their duties guided them. He speaks always in terms not of himself alone but of his children. Even the beasts of the field he would redeem from the curse of the fruit. Yet, finally, in spite of all that is courageous and highminded in his opposition, the taint of envy and revenge leads him to confuse service with personal gratification, and he who desired to be free of death and to free men, leads Death into the world for the first time. Cain had attained no inner unity, although the "duty of humanity" may be said to have been emerging into a central place.

Between those early heroes, like Conrad and Lara (1814), and Cain (1821) there is a transition group represented by Manfred (1817). Manfred seeks oblivion, self-oblivion." He has found that "The tree of Knowledge is not that of life. In him courage, firmness, and patience have gathered power over men and over material and over spirits. Yet all's but

\footnotetext{
6s See Froude, Thomas Carlyle, I, 216.
}

${ }^{6}$ Cain, Act I, Scene 1. 
naught. His taint was ambition; for though he could say I have done men good, And I have met with good even among men,-67

he was not content. "This avail'd not." He could not define life in duties, he asserted and exercised the arrogant rights of a satanic spirit. In the Hall of Arimanes, a spirit of evil admires him.

\footnotetext{
Yet, see, he mastereth himself, and makes

His torture tributary to his will.

Had he been one of us, he would have made

An awful spirit. ${ }^{68}$
}

Manfred had never that desire to free men which animated Cain, and he never came to humiliate himself as did Cain. As a character, he looks forward toward the condition in which service is a goal and humility a reaction upon arrogance. But he is none the less still very much like those who protested vigorously against their world. He does not fall into mere vociferous despondency, as they, however,until he has conquered. Then he is overwhelmed by the desperate boredom of omniscience, without love. As a fact it seems to me, Manfred can not accurately be called Promethean; he can not even be called Satanic. He typifies the degree of rebellion beyond the vague sullenness of Lara but this side the intelligent opposition of Cain and Lucifer. Such is the Byronic Rebel.

With respect to the thought of Wordsworth, of Coleridge, of Byron, and of Shelley, it is, then, possible to expound the phrase "the permanent politics of human nature." Such an interpretation confirms and indeed constitutes a gloss upon Mr. Graham's assertion that, with these poets, "a deeper expediency of humaneness and justice" regulated the political outlook. It reveals their philosophy of politics, not their practice. And yet it makes clear that the "change of political face" in Wordsworth and in Coleridge was not

${ }^{67}$ Manfred, Act I, Sc. I.

68 Ibid., Act II, Sc. IV. 
apparent but real, and that it consists largely of the introduction of a leader into the Jacobinical formula. And, finally, it seems to me to raise seriously the question whether one can say even of Shelley and Byron that their politics "were upon an emotional basis." For in each of the four-whatever his success-there is a powerful effort of thought directed toward a solution of the permanent human problem of leadership.

B. H. LeHMaN 



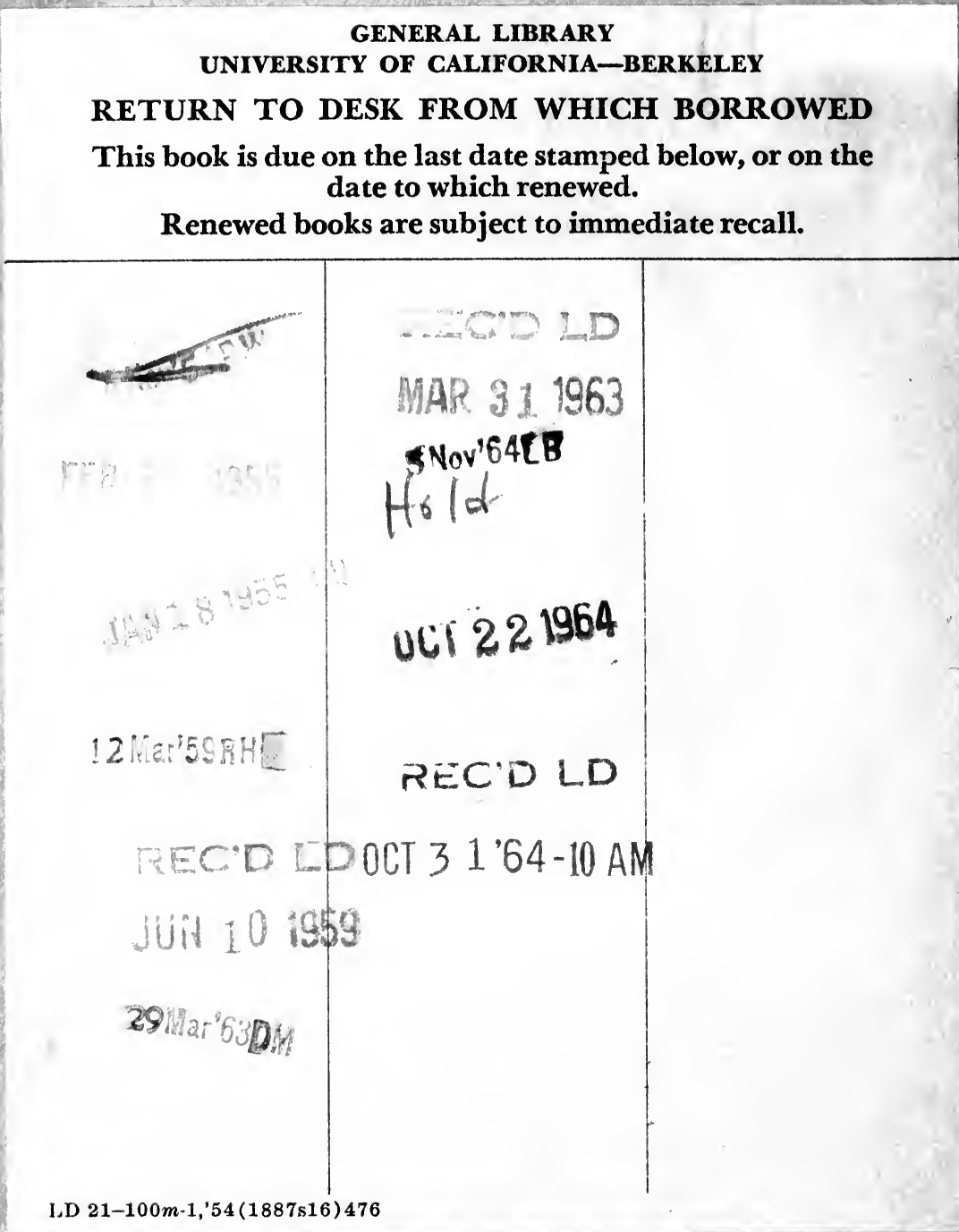




\section{GAYLORD}

BROS., INC. , Menusecturoro

Syracuse, N. Y. Stockton, $C_{t}$ iti. 
$x+2 y^{2}$

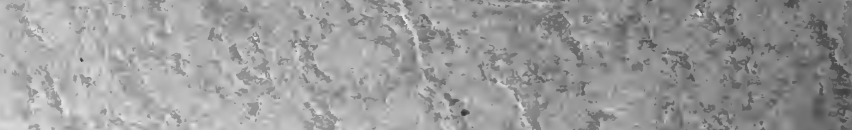

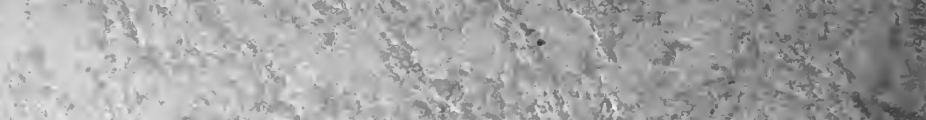
3.t.

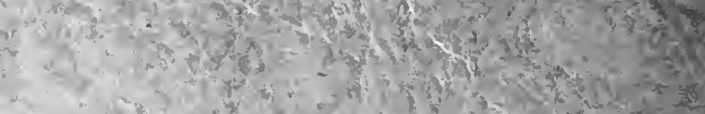

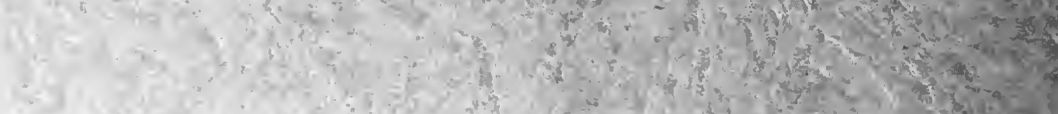

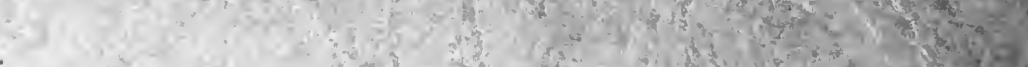

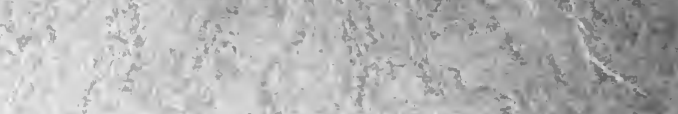

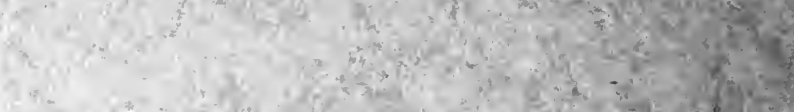

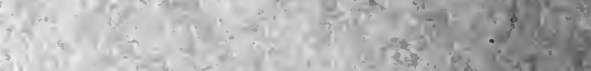

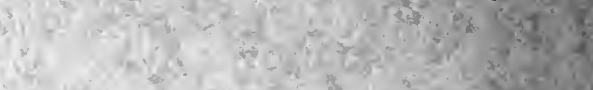

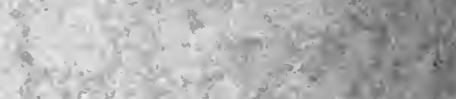

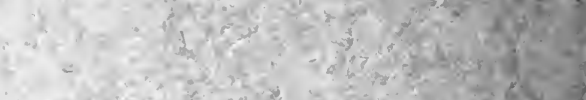

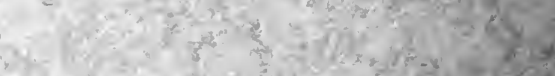

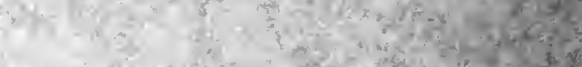

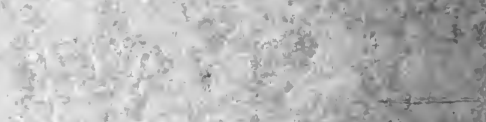

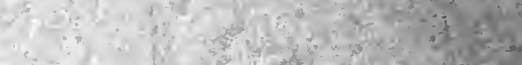

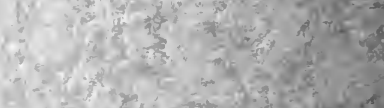
Dikt $2+x^{2}-2=0$

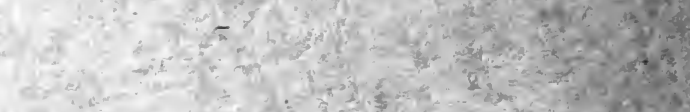

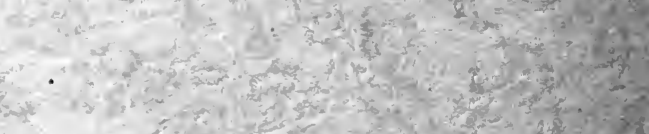

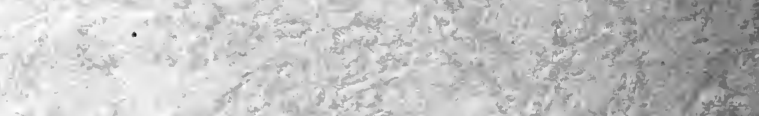

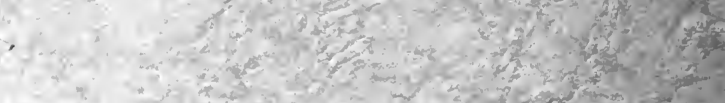

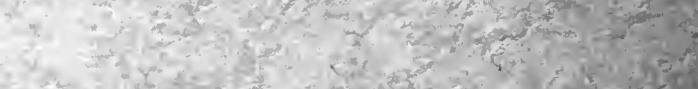
$+2 x+y=2 x=$

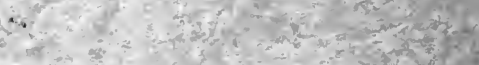
$x^{2}$

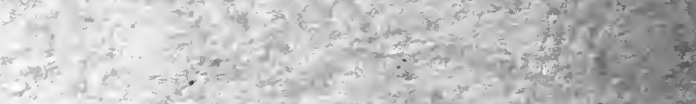

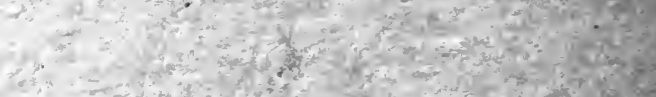
$=\frac{x^{2}}{3 x^{2}}$

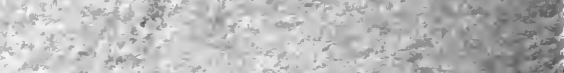

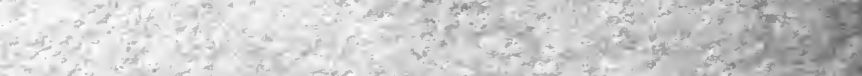

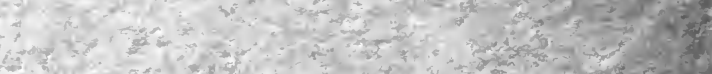
.

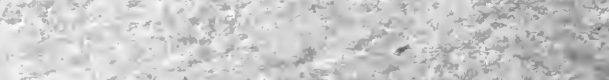

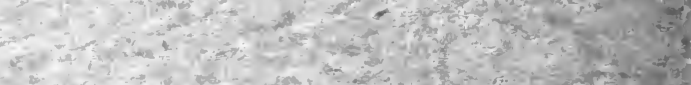
an

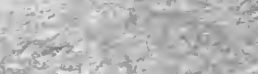

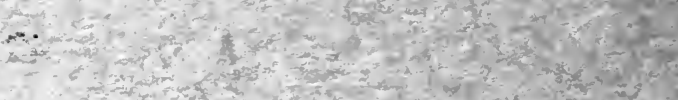

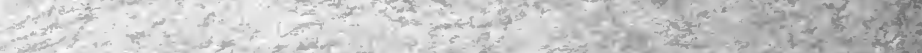

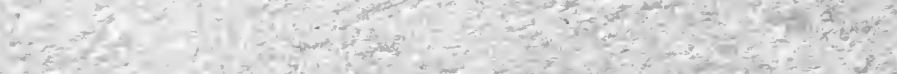

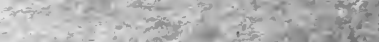

